\title{
Sphaeropsis sapinea and fungal endophyte diversity in twigs of Scots pine (Pinus sylvestris) in Germany
}

\author{
Johanna Bußkamp $^{1,2}$ (D) $\cdot$ Gitta Jutta Langer ${ }^{1}$ E Ewald Johannes Langer ${ }^{2}$
}

Received: 20 April 2020 / Revised: 11 August 2020 / Accepted: 13 August 2020

(C) The Author(s) 2020

\begin{abstract}
Sphaeropsis sapinea is the causal fungal agent of Diplodia tip blight disease of Scots pine (Pinus sylvestris) and other coniferous trees of relevance to forestry in Germany. In this study, the distribution and occurrence of $S$. sapinea and accompanying endophytic fungi in twigs of healthy and diseased Scots pine was investigated on a spatial and temporal scale. Sampling of 26,000 twig segments from trees in 105 temperate coniferous forest stands in Germany resulted in isolation of 33,000 endophytic fungi consisting of 103 species identified based on morphological and ITS-DNA sequence analyses. Approximately $98 \%$ of the sample was represented by fungi in the Ascomycota, with only two species (Peniophora pini and Coprinellus sp.) belonging to the Basidiomycota. Four species were detected in a frequency greater than 10\% (Sphaeropsis sapinea, Sydowia polyspora, Microsphaeropsis olivacea, and Truncatella conorum-piceae) from the collective sample. A typical inhabitant of Scots pine twigs Desmazierella acicola was isolated and additionally typical hardwood colonizers like Biscogniauxia spp. were detected. S. sapinea, an endophytic plant pathogen with saprobic capabilities, was isolated from more than $80 \%$ of the studied pine trees, but the majority of trees sampled showed no symptoms of Diplodia tip blight. No invasive, pathogenic quarantine fungi for Germany were isolated from healthy or diseased Scots pines. Advantages and disadvantages of isolation-based endophyte studies over studies using direct DNA-isolation are discussed. Knowledge of the fungal endophyte communities in twigs of Scots pine allowed for identification $S$. sapinea and other potential pathogens of pines and other forest trees that may possibly contribute to increased disease under repeated periods of drought and heat stress in the future.
\end{abstract}

Keywords Endophytic fungi $\cdot$ Pinus sylvestris $\cdot$ Sphaeropsis sapinea $\cdot$ Diplodia tip blight

\section{Introduction}

Scots pine (Pinus sylvestris L.) is one of the most important conifer tree species in Northern and Central Europe. In Germany, this tree species is a very important factor in forest and timber management and economics. Natural Scots pine

Section Editor: Marc Stadler

Electronic supplementary material The online version of this article (https://doi.org/10.1007/s11557-020-01617-0) contains supplementary material, which is available to authorized users.

Johanna Bußkamp

johanna.busskamp@nw-fva.de

1 Department of Forest Protection, Northwest German Forest Research Institute (NW-FVA), D-37079 Göttingen, Germany

2 Fachbereich 18 Naturwissenschaften, Institut für Biologie, Fachgebiet Ökologie, Universität Kassel, Kassel, Germany forests are rather rare in Germany, due primarily to its low competitiveness compared with other, more shade tolerant tree species such as European beech (Fagus sylvatica L.). Therefore, native pine forests are restricted to azonal vegetation types, for example, sand dunes or the edges of moors or moorlands. Most of the natural forests with Scots pine as the main tree species are found in Northeastern Germany. $P$. sylvestris has a wide ecological amplitude (Ellenberg and Leuschner 2010), it is considered to be a stress tolerant, easy to regenerate, versatile, and light demanding pioneer species. Typical for Northern parts of Germany are secondary or manmade pine stands. With ca. 2.4 million hectares, $P$. sylvestris has a $22.9 \%$ share of the German forested area (ThünenInstitut 2014); however, areas forested with pine are decreasing. This decline has several causes, but risk factors, such as global climate change and new or emerging fungal diseases, play an important role (Mason and Alía 2000; Drenkhan et al. 2016). Scots pine forests covers 28 million hectares in Europe and thus make up $20 \%$ of the commercial forest area of the European Union (Mason and Alía 2000). 
Sphaeropsis sapinea (Fr.) Dyko \& B. Sutton (syn. Diplodia pinea (Desm.) J. Kickx f.) is recognized as the most widespread necrotrophic ascomycete pathogen responsible for dramatic losses of pine trees across the continents (Fabre et al. 2011; Phillips et al. 2013). It spreads from needles via stomata or injured tissue into the host and results in disease symptoms that include tip blight, stem canker, dieback of current year shoots, and blue staining of sapwood (Brookhouser and Peterson 1971; Munck et al. 2009). It is also known to be present and persistent as a symptomless endophyte in pine twigs (Langer et al. 2011; Fabre et al. 2011; Luchi et al. 2014). Pathogenic occurrence of $S$. sapinea can be triggered by stress, which is particularly important in the context of climate change with precipitation deficits and increased temperatures that weaken pine (Fabre et al. 2011; Bosso et al. 2017). This species of the Botryosphaeriaceae family has appeared as a pathogen in Central Europe since the 1980s (Swart and Wingfield 1991). In Germany, infections of Scots pines and Austrian pines (Pinus nigra J.F. Arnold) by S. sapinea causing serious forest health problems were observed in the middle of the 1990s by Heydeck and Dahms (2012) and later by Langer et al. (2011). The geographical origin of the native distribution of S. sapinea is not known (CABI 2014) and it is questionable whether the species is native to Europe (DesprezLoustau et al. 2009). Knowledge of the latent distribution of $S$. sapinea in Germany and occurrence of other potential pine pathogens or quarantine pests is of great interest. The aim of this study is to determine the composition of cultivable fungal endophytes (in the sense of Petrini (1991)) of Scots pine in Germany at the species level and to assess the taxa regarding their significance for forestry.

The distribution of $S$. sapinea in Germany, and environmental factors triggering the outbreak of disease symptoms after a period of symptomless existence of S. sapinea in apparently healthy twigs of pines, were studied by Bußkamp (2018) in a doctoral thesis. Results of that research are presented as part of this study. The fungal endophytes of pine branches were previously studied by Kowalski and Kehr (1992). Various other authors have studied diverse tissues of Scots pine with regard to colonization by mycobiota (Carroll et al. 1977; Petrini and Fisher 1988; Fisher et al. 1991; Kowalski and Kehr 1992; Kowalski 1993; Pirttilä et al. 2003; Lygis et al. 2004; Pinto et al. 2006; Menkis et al. 2006; Kwaśna 2008; Giordano et al. 2009; Menkis and Vasaitis 2010; Peršoh et al. 2010; Terhonen et al. 2011; MartínezÁlvarez et al. 2012; Romeralo et al. 2012; Sanz-Ros et al. 2015; Millberg et al. 2015). In contrast to the aforementioned studies, in this work the incidence of disease and endophytic occurrence of $S$. sapinea was investigated on a German spatial base with a large and comprehensive spatial and temporal sample. Additionally, an assessment of the endophytes concerning their lifestyles, trophic status, and relevance to forest health is presented.

\section{Materials and methods}

\section{Sample collection}

From 2014 to 2016, in different seasons, twigs were sampled from Scots pine (Pinus sylvestris L.) from 105 forest sites in Germany by climbing or felling trees or by archery (Fig. 1 and supplementary Table). A systematic sampling approach was used to collect $P$. sylvestris twigs along a transect from the Northeast to the Southwest of Germany in climate sensitive regions (91 sites, Fig. 1). Transect sampling was conducted at grid points of the Forest Condition Survey grid (ThünenInstitut 2020); and 14 additional pine stands were also examined with at least 6 trees per stand being sampled (Fig. 1). Trees sampled from the latter stands were diseased by Diplodia tip blight and were also infested with phyllophagous insects (e.g., Dendrolimus pini L., Thecodiplosis brachyntera Schwägrichen) or mistletoe (Viscum album subsp. austriacum (Wiesb.) Vollm.) at the time of sampling. At the localities Pfungstadt, Bad Freienwalde, and Lüderitz, pairwise comparisons of stands with healthy and diseased trees were performed. Monthly sampling, over a period of 13 months (September 2015-October 2016), of twigs collected from a single tree was carried out in a forest stand close to the city of Dransfeld in the South of Lower Saxony (Fig. 1). Sampled trees were older than 50 years and located 20 to $600 \mathrm{~m}$ above sea level in stands that were dominated by Scots pine. Most stands were secondary man-made forests, partially outside the natural range of Scots pine (EUFORGEN 2008). Three shoot tips per tree were arbitrarily selected, placed in a sterile plastic bag and transported in a cool box $\left(8^{\circ} \mathrm{C}\right)$ to the laboratory. Twig samples were divided into two categories based on occurrence of Diplodia tip blight symptoms (healthy twigs from trees with symptoms $(n=\sim 2800$ samples/segments $)$ and twigs from trees without symptoms ( $n=\sim 23,000$ samples/ segments)). Ocular visible symptoms of Diplodia dieback of shoots and browning of the crown were also recorded. Symptomatic branches were examined in the laboratory for the presence of Sphaeropsis sapinea (Fr.) Dyko \& B. Sutton.

\section{Isolation and determination of fungi}

Three randomly selected tips per tree from 3 to 4 -year-old branches ( $n=190$ P. sylvestris trees) were defoliated, washed, and surface disinfested by treating for $1 \mathrm{~min}$ in $70 \% \mathrm{EtOH}$, $5 \mathrm{~min}$ in a $3 \% \mathrm{NaOCl}$, and $1 \mathrm{~min}$ in $70 \% \mathrm{EtOH}$ (Bußkamp 2018). Pre-treatments (washing and brushing), different disinfestation methods (duration of soaking, concentration of $\mathrm{NaOCl}$ ), and post-treatments (washing in water or $\mathrm{EtOH}$, drying method) were tested in preliminary experiments (data not shown). The method selected for this study was verified by additional testing (imprinting, rolling in sporulating cultures of previously disinfested twigs and plating of rinse water, 
Fig. 1 Sampling sites in Germany 2014-2016; ( GeoBasis-DE / BKG 2014 and (C) EuroGeographics

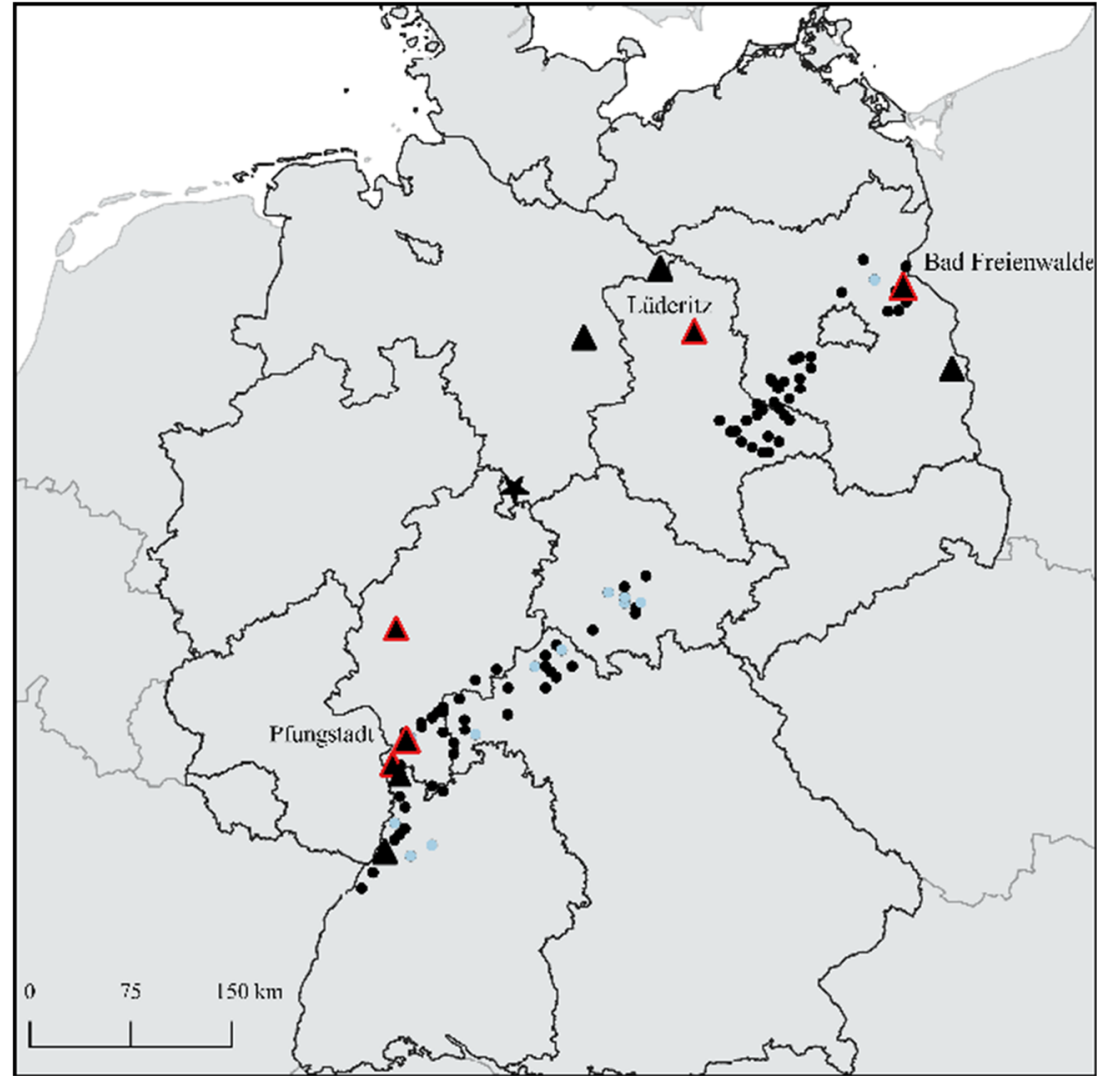

* Dransfeld, monthly sampling

$\boldsymbol{\Delta}$ infection by S. sapinea causing symptoms; intensively examined plots

A latent infection by S. sapinea; intensively examined plots without S. sapinea; Forest condition survey grid

- latent infection by S. sapinea; Forest condition survey grid followed by monitoring of fungal growth). Thereafter, twigs were cut into 5-mm length pieces (hereinafter referred to as segments), plated on malt yeast peptone agar (MYP) modified according to Langer (1994) containing 0.7\% malt extract (Merck 1.05391.0500, Darmstadt, Germany), 0.05\% yeast extract (Fluka 70,161-100G, Seelze, Germany), 0.1\% peptone (Merck 1.07272.0500), and 1.5\% agar (Fluka 05040-1KG). Usually, 3 twig segments were placed on MYP medium in a 90-mm-diameter plastic Petri dish and incubated for up to 3 weeks at room temperature (ca. $22^{\circ} \mathrm{C}$ ) and ambient daylight. Twig segments were visually checked, weekly, for developing colonies. Emerging mycelia were sub-cultured separately on MYP medium. Isolated strains were initially assigned to mycelial morphotypes (MTs) further characterized based on micro-morphological characters and DNA sequence analysis. Representative fungal strains were stored on MYP slants at $4{ }^{\circ} \mathrm{C}$.

From each morphotype, 1-2 mg of culture tissue was suspended in $100 \mu \mathrm{TE}$ buffer in a $1.5-\mathrm{ml}$ tube. A microwave $(600 \mathrm{~W})$ was used twice for $1 \mathrm{~min}$ each time, with a pause of $30 \mathrm{~s}$, to break up cells. Tubes were cooled to -
$20{ }^{\circ} \mathrm{C}$ for $20 \mathrm{~min}$ and centrifuged at $10000 \mathrm{rpm}$ for $5 \mathrm{~min}$. A 100 times diluted portion of the supernatant was used for DNA with the polymerase chain reaction (PCR). Primer pairs for amplification of the ITS1, 5.8S, and ITS2 regions were ITS1F/ITS4 or ITS1/ITS4 (White et al. 1990; Gardes and Bruns 1993). PCR was performed with 45- $\mu$ l Master mix from QIAGEN, Hilden, Germany, where $5 \mu$ l of extracted DNA was added. PCR was carried out using the primer pairs, with initial denaturation at $94{ }^{\circ} \mathrm{C}$ for $3 \mathrm{~min}$, followed by 29 cycles of denaturation at $94{ }^{\circ} \mathrm{C}$ for $30 \mathrm{~s}$, annealing at $55^{\circ} \mathrm{C}$ for $45 \mathrm{~s}$, and extension at $72{ }^{\circ} \mathrm{C}$ for $60 \mathrm{~s}$; final elongation was performed at $72{ }^{\circ} \mathrm{C}$ for $7 \mathrm{~min}$. PCR products were separated on $1 \%$ agarose gel stained with GelRed fluorescence dye (Biotium, Hayward, CA, USA), followed by a cleaning with QIAquick PCR Purification Kit (QIAGEN, Hilden, Germany). Sanger sequencing of purified products (Sanger et al. 1977) was commissioned at GATC Biotech (Cologne, Germany). Editing and alignment of DNA sequences were performed with MEGA6 (Tamura et al. 2013) followed by submission to GenBank (Table 1). 
For identifying MTs, a ZEISS Axiostar plus microscope was used and the standard procedures for fungi described in Lee and Langer (2012) were followed. In addition to standard literature recommended by Oertel (2003) for determination of fungi and forest diseases, the following literature was used, e.g., Guba 1961; Booth 1971; Domsch et al. 1993; Arx 1981; Gerlach and Nirenberg 1982; Breitenbach and Kränzlin 1984; Ju et al. 1998; Verkley 1999; Samson et al. 2010; and Butin 2011. Names of fungal species follow Index Fungorum (www. indexfungorum.org). At least one representative strain of each morphotype was used for DNA sequence analysis. Sequences were submitted to GenBank and the BLAST algorithm (http:// www.ncbi.nlm.nih.gov/genbank, Altschul et al. 1997) was used for fungal taxon confirmation. Intraspecific ITS sequence similarity of $98-100 \%$ was used to determine species identity. Query coverage of all taxa was between 90 and $100 \%$. Except for Truncatella conorum-piceae (54\%) where there was only a single reference for comparison, the arithmetic mean of overlap was $97.7 \%$. The frequency of each fungal species sampled from twigs was specified as the percentage of this particular fungus in all outgrowing fungi.

The map (Fig. 1) was made using QGIS (www.qgis.org). Evaluation of the endophyte data was analyzed using ordination (Detrended Correspondence Analysis and Canonical Correspondence Analysis, data not shown); test of significance was performed using R (R Core Team 2019, www.r-project.org).

\section{Results}

From 190 analyzed trees at 105 sites, 103 species of endophytic fungi were sampled (Table 1). With 101 species belonging to the Ascomycota and two species to the Basidiomycota (Peniophora pini (Schleich. ex DC.) Boidin and Coprinellus sp.). No fungi were recovered from approximately $5 \%$ of the sampled twig segments.

Fungi belonging to the Pleosporales represented the most frequent sample group of fungi (27\% of the isolated strains) and showed a high species-richness (19 species: Alternaria alternata (Fr.) Keissl.; A. infectoria E.G. Simmons; Alternaria sp., Drechslera sp., Epicoccum nigrum Link; Microsphaeropsis olivacea (Bonord.) Höhn.; Paraphaeosphaeria neglecta Verkley, Riccioni, \& Stielow; Pa. verruculosa Verkley, Göker, \& Stielow; Periconia sp., Phoma eupyrena Sacc., 4 unidentified Phoma species, 2 unidentified Preussia species, and 3 unidentified Pleosporaceae), whereas, e.g., the Dothideales grew out frequently (22\% of the species belong to Dothideales), but only one species was detected in this order (Sydowia polyspora (Bref. \& Tavel) E. Müll.). Ca. 13\% of the isolated strains were assigned to Botryosphaeriales (2 species: Camarosporium brabeji Marinc., M.J. Wingf. \& Crous and Sphaeropsis sapinea), and respectively 10\% Amphisphaeriales (3 species: Microdochium nivale (Fr.)
Samuels \& I.C. Hallett, Truncatella conorum-piceae (Tubeuf) Steyaert, and Truncatella sp. 2), 9\% Xylariales (19 species: Arthrinium kogelbergense Crous, Biscogniauxia mediterranea (De Not.) Kuntze, B. nummularia (Bull.) Kuntze, Daldinia childiae J.D. Rogers \& Y.M. Ju, D. concentrica (Bolton) Ces. $\&$ De Not., Daldinia sp., Hypoxylon fragiforme (Pers.) J. Kickx f., H. rubiginosum (Pers.) Fr., Nemania diffusa (Sowerby) Gray, $N$. serpens (Pers.) Gray, two unidentified Pestalotiopsis species, two unidentified Rosellinia species, Xylaria longipes Nitschke, X. polymorpha (Pers.) Grev., and three unidentified Xylaria species), 5\% Sordariales (10 species: Chaetomium globosum Kunze, two unidentified Chaetomium species, Jugulospora rotula (Cooke) N. Lundq., Podospora curvicolla (G. Winter) Niessl, Sordaria fimicola (Roberge ex Desm.) Ces. \& De Not., two unidentified Sordaria species, Trichocladium sp., and an unidentified Sordariales species), 5\% Diaporthales (10 species: three not further identified Apiognomonia species, Cytospora sp., four unidentified Diaporthe species, Plagiostoma sp., and an unidentified Gnomoniaceae), 4\% Helotiales (8 species: Botrytis cinerea Pers., Lambertella sp., Pezicula cinnamomea (DC.) Sacc., P. eucrita (P. Karst.) P. Karst., P. neosporulosa Z.L. Yuan \& Verkley, two unidentified Pezicula species, and Phacidium lacerum Fr.), and 2\% Pezizales (5 species: Chromelosporium carneum (Pers.) Hennebert, Desmazierella acicola Lib., Peziza varia (Hedw.) Alb. \& Schwein., Pyronema domesticum (Sowerby) Sacc., and an unidentified Pezizales species). The rest of the isolated species occurred with a lower abundance in the study: 6 species of the Hypocreales (Trichoderma sp., Lecanicillium psalliotae (Treschew) Zare \& W. Gams, Fusarium sp., Fusarium sp. 1, Fusarium solani complex, and Beauveria bassiana (Bals.-Criv.) Vuill.), Nigrospora oryzae (Berk. \& Broome) Petch, Nigrospora sp., two Capnoidales species (two Cladosporium sp.), three Coniochaetales (two Lecythophora species and Coniochaeta ligniaria (Grev.) Cooke, a single Eurotiales (Penicillium sp.), a single Umbelopsidales (Umbelopsis isabellina (Oudem.) W. Gams), and few other Ascomycota not determined to the order level (Fig. 2 and Table 1).

Four fungal species were sampled with a frequency higher than $10 \%$ as follows: M. olivacea (23\%), Sy. polyspora (22\%), S. sapinea (12\%), and T. conorum-piceae (10\%). Fifteen species had a frequency exceeding $1 \%$. All other species were isolated less often. S. sapinea, M. olivacea, Sy. polyspora, T. conorumpiceae, So. fimicola, and A. alternata were isolated from more than $50 \%$ of sampled trees. The most common species were isolated from more than $80 \%$ of the studied stands along the transect: Sy. polyspora (99\%), T. conorum-piceae (98\%), M. olivacea $(97 \%)$, and S. sapinea (88\%). Other fungi that were found in more than $50 \%$ of the study areas were as follows: Diaporthe sp. 2 and A. alternata as well as Ne. serpens. Neither fungal quarantine pests (according to EPPO A1 and A2 List (EPPO 2020a, b)) nor alien species (Desprez-Loustau 2009) for Germany were identified. The following 24 species 


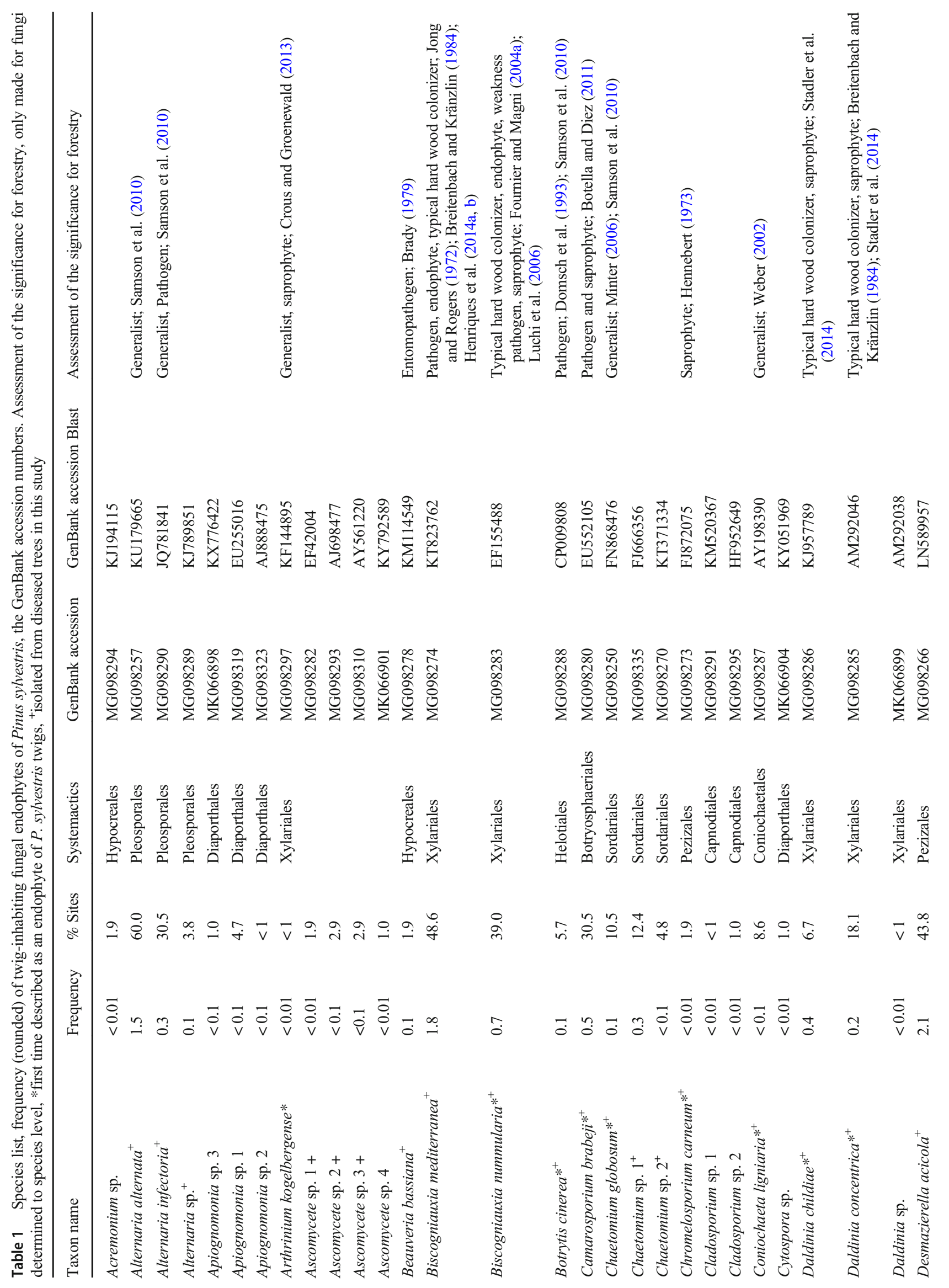




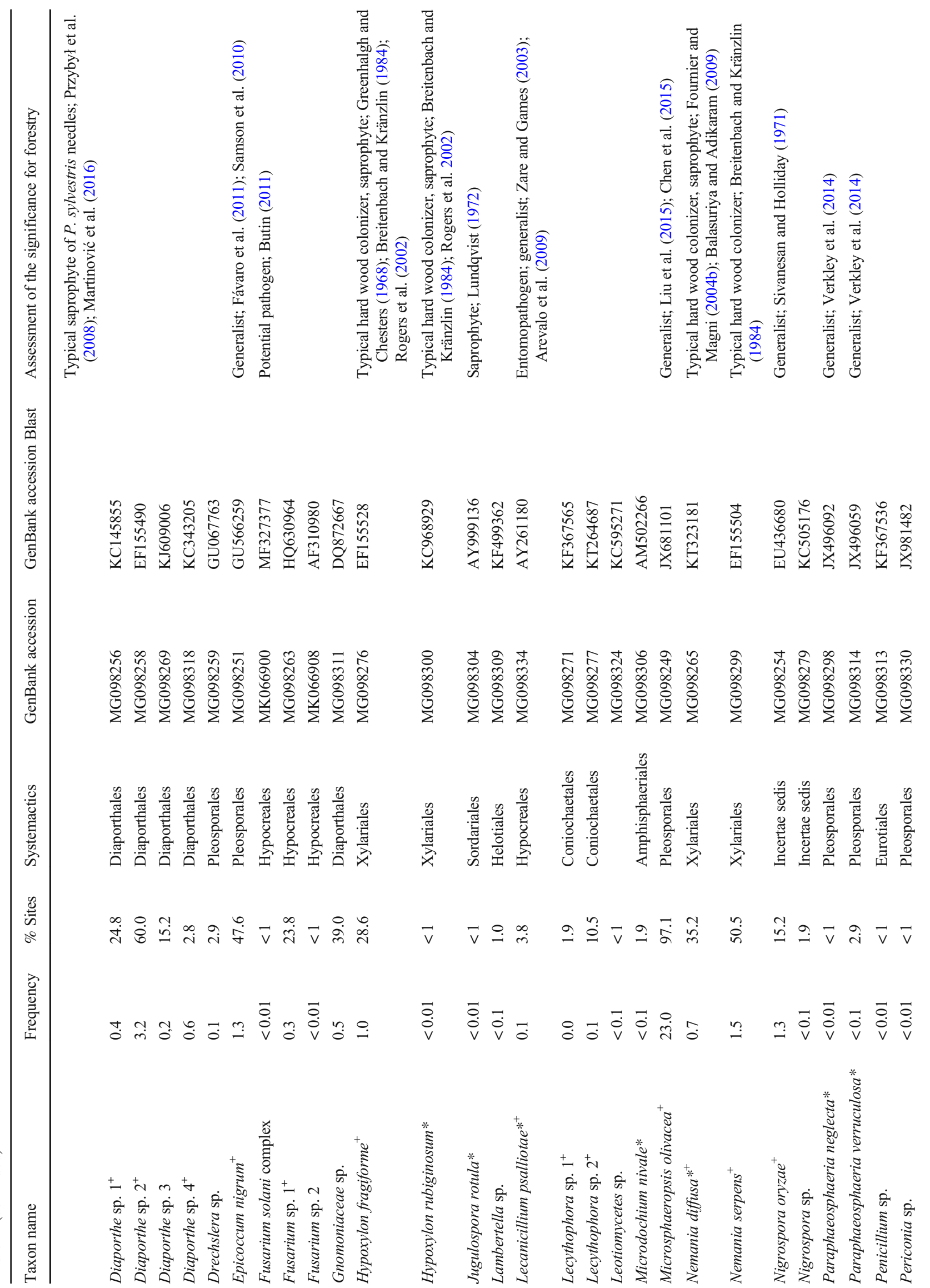



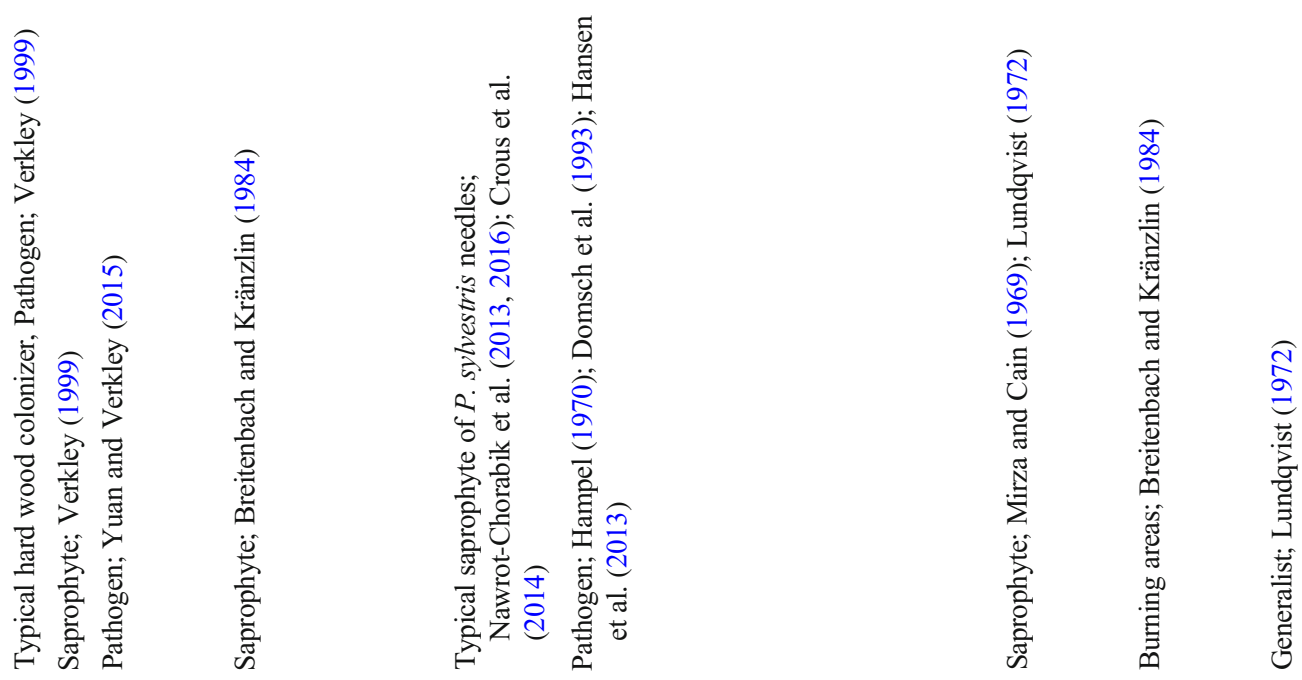

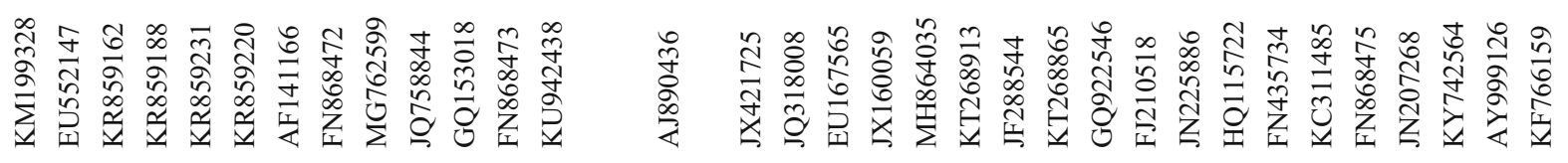

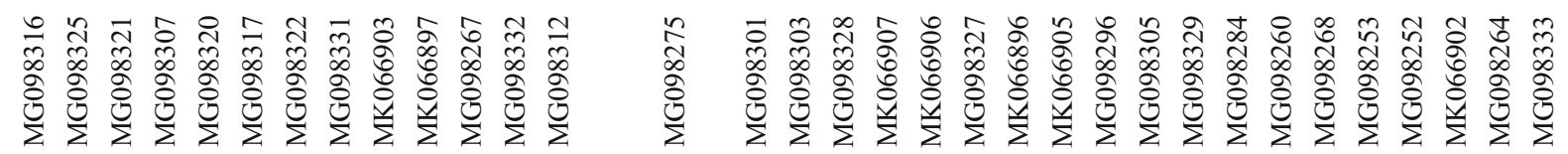

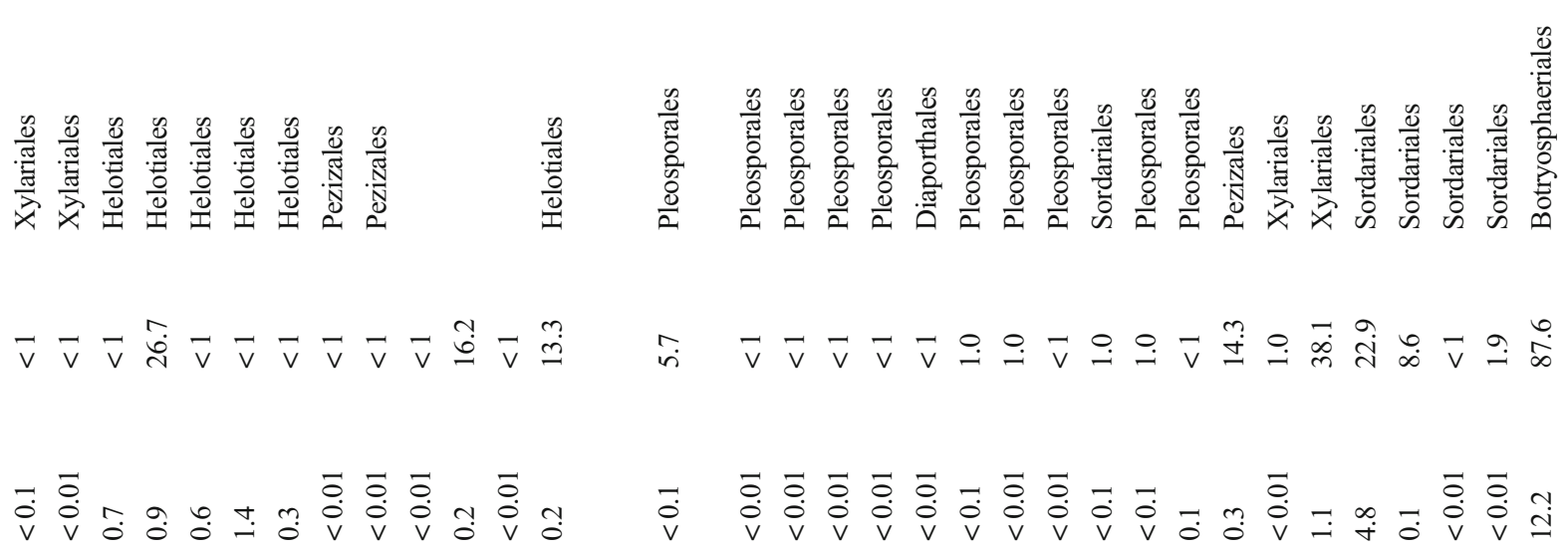




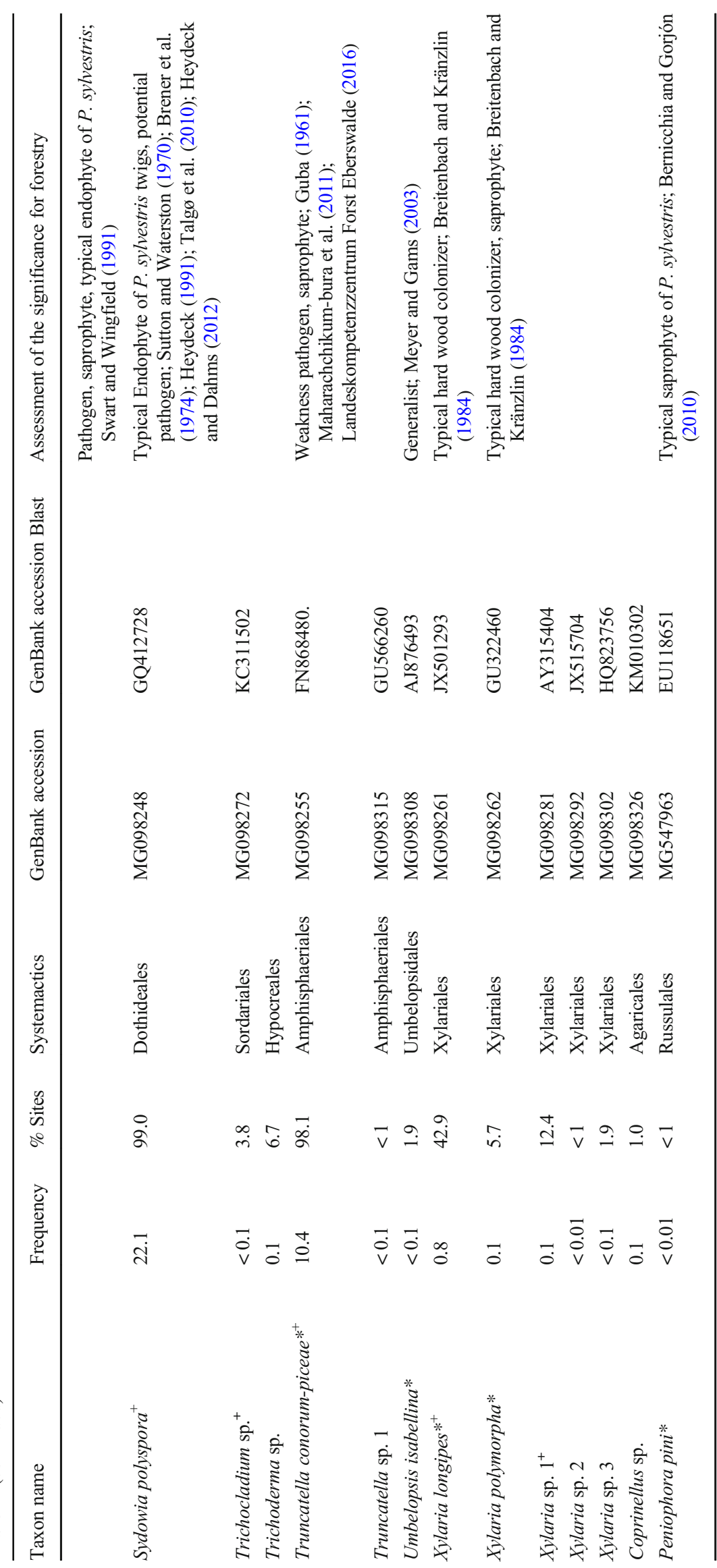


Fig. 2 Frequency of isolated fungi based on their respective taxonomic orders $(n=\sim 33,000)$. Relative species frequency and portion of species numbers of fungal orders in relation to total number of proved species $(n=$ 103), not determined represents species where no classification to order level was possible or Incertae sedis: Nigrospora oryzae, Pezizomycetes sp. 1, Nigrospora sp., Ascomycete spp., Leotiomycetes spp.)
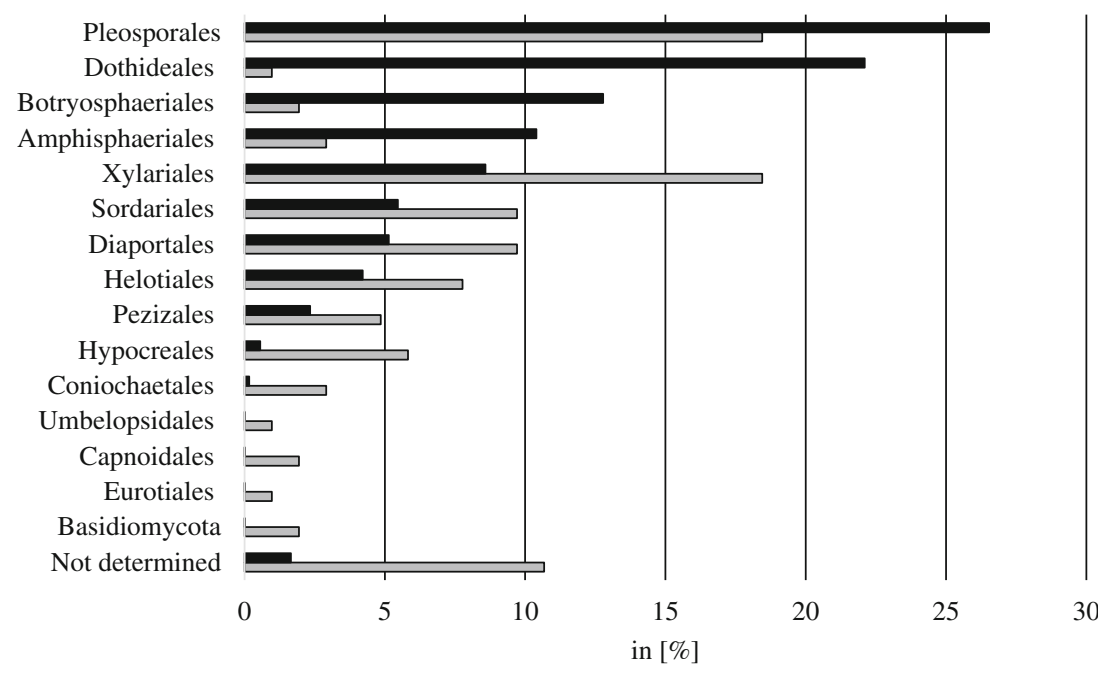

30

\% Relative species frequency $\square \%$ of Species

were found as endophytes in pine twig for the first time: $A r$. kogelbergense, B. nummularia, Bo. cinerea, Ca. brabeji, Ch. globosum, Co. ligniaria, Chr. carneum, Da. childiae, Hy. rubiginosum, Ju. rotula, Le. psalliotae, Mi. nivale, Ne. diffusa, Pa. neglecta, Pa. verruculosa, Pen. pini, Pez. neosporulosa, Pez. varia, Ph. eupyrena, Py. domesticum, Po. curvicolla, T. conorum-piceae, $U$. isabellina, and $X$. polymorpha (Table 1 , species denoted with a plus * symbol).

Along the transect, 5-22 endophyte species per tree were detected, on average 13 species per plot. The number of identified species per plot increased with the number of investigated samples. Typically three pine twigs were sampled per tree (between 22 and 213 studied segments per tree). But a single tree located in the sampling area "Dransfeld" was sampled monthly over 13 months ( $\sim 7500$ studied segments) and 84 species were isolated. Seasonal differences in the frequency and number of species were apparent. For this tree, the colonization rate (number of species and frequency) was lower in December to March than from April to November. The occurrences of Sy. polyspora and M. olivacea contrasted, with $S y$. polyspora dominating in the summer months (June-July) and M. olivacea in December-March.

At least one S. sapinea-strain was sampled from $88 \%$ of the 105 studied pine stands. In forest stands without symptoms of Diplodia tip blight, $S$. sapinea was detected with a relative frequency ranging from 0 to $68 \%$. The analysis of the endophytic occurrence of $S$. sapinea along the studied transect across Germany exhibited that geographic longitude and altitude do not significantly influence the occurrence of the dieback fungus. However, $S$. sapinea tended to be isolated in a lower frequency at sites with higher altitudes (Pearson correlation coefficient $=-0.29$ ).

From diseased tree twig samples, 45 fungal species were isolated (See Table 1, species denoted with a plus + symbol).
All species of endophytic fungi found in diseased trees could also be isolated from trees without symptoms. A pairwise comparison of sites with and without symptoms of Diplodia tip blight revealed that the number of endophytic species isolated in trees with and without symptoms at sites in Pfungstadt and Bad Freienwalde were similar (Pfungstadt 34 and 33 species respectively, Bad Freienwalde in each case 23 species), with the occurrence of the different species also varying little between symptomatic and symptom-free trees in intensively examined stands. However, differences were found between healthy and diseased trees with regard to the infection rate with S. sapinea: $9 \%$ in healthy trees and $40 \%$ in diseased trees. In all three comparative pairs (Pfungstadt, Bad Freienwalde, and Lüderitz), the frequency of occurrence of $S$. polyspora and Desmazierella acicola were higher in healthy trees.

Twelve isolated species were identified as potential pathogens on woody plants as follows: A. infectoria, B. mediterranea, B. nummularia, Bo. cinerea, Ca. brabeji, Fusarium solani complex, Pez. cinnamomea, Pez. neosporulosa, Ph. eupyrena, S. sapinea, Sy. polyspora, and T. conorum-piceae (Table 1).

\section{Discussion}

The comparison of the endophyte fungal twig communities of diseased and non-diseased Scots pine trees revealed few differences. Except $S$. sapinea, there were no isolated species which occurred or were specific to diseased Scots pines. Botella et al. (2010) detected Sy. polyspora in twigs of diseased Aleppo pine. Additionally, several other potentially pathogenic fungi, e.g., Gremmeniella abietina (Lagerb.) M. Morelet, Cytospora sp., Naemacyclus niveus (Pers.) Fuckel ex Sacc., and Pestalotia stevensonii Peck were observed by Botella et al., but these pathogens were not found in the tested Scots pine twigs in the present 
study. Sy. polyspora was isolated on nearly every studied site (99\%) in this study. On the one hand, it was classified as a typical endophyte because no pathogenic occurrence (no typical disease symptoms) was observed in all tested trees. On the other hand, it could be assessed as a potential pathogen for (coniferous) trees based on various published studies (Table 1).

It was apparent that pines with Diplodia tip blight studied in Germany exhibited a very high rate of infection with $S$. sapinea $(\sim 40 \%)$. Although high rates of infection were, rarely, also found in symptomless and vital pine stands (e.g., 68\% S. sapinea at a sampling point in Hesse), the average rate of infection of symptomless pines was lower $(\sim 9 \%)$. The number of species isolated from diseased trees was generally less $(n=45$, see Table 1$)$ than those isolated out of symptomless pines $(n=103)$. This may be partially explained by the fast growth of $S$. sapinea in culture (Slippers and Wingfield 2007; Decourcelle et al. 2015), which possibly resulted in an underrepresentation of slow-growing fungal species. The sample numbers for the two categories (symptomless and Diplodia-diseased pines) in this study differed (2800 tested twig segments of pine twigs from trees with symptoms or 23,000 without symptoms of the Diplodia tip blight). This was probably the most significant influence on the detected number of species. In this study, S. sapinea was isolated from twigs with a relative frequency of $12 \%$ (mean value for all examined twig segments). From $88 \%$ of the 105 examination sites, it was possible to isolate at least one $S$. sapinea strain. The endophytic occurrence of $S$. sapinea in this study, measured in frequency of colonization, is higher than in other studies like by Bihon et al. (2011), Flowers et al. (2001, 2003), and Maresi et al. (2007). Bihon et al. (2011) assumed that the low isolation frequency of endophytic $S$. sapinea could be explained by the specific position of its propagules in symptomless pine tissue. The colonization with $S$. sapinea in buds and bark of black pine is not continuous, as presented in the study of Flowers et al. (2003). In their experiment, they bisected buds and bark and could not always isolate S. sapinea from both parts. Maresi et al. (2007) detected more endophytic growing $S$. sapinea strains with the PCR-method, compared with using isolation on nutrient media, from twigs of black pine. There are $S$. sapinea selective media, such as Swart's medium (Swart et al. 1987) or Blodgett's medium (Blodgett et al. 2003). Rigling et al. (1989) described the highest frequency of isolation on Bavendamm's medium. In our opinion, the use of a selective medium is not always necessary, since $S$. sapinea grows well, fast, and competitive on the used MYP medium.

On sites with a higher altitude, $S$. sapinea tended to be isolated with a lower frequency. This tendency was first described by Fabre et al. (2011) who also found a decrease in S. sapinea colonization of pine cones with increasing elevation. These researchers assume, therefore, that the milder temperature in winter at sites with lower elevation could be an explanation. In this study, the range in height of the examined sites was between $\sim 20$ and $600 \mathrm{~m}$ above sea level, while the researcher group around Fabre et al. (2011) examined sites up to $\sim 1500 \mathrm{~m}$ above sea level.
The widespread latent/endophytic infection of pines with $S$. sapinea constitutes a danger to weakened pine stands. It is presumed that $S$. sapinea already present in a pine can easily change from endophytic to parasitic lifestyle in a weakened host. In greenhouse experiments, Stanosz et al. (1997) and Flowers et al. (2001) proved that $S$. sapinea strains obtained from healthy pine tissues show an equally high pathogenic potential as those strains obtained from diseased tissues. Usually numerous pycnidia of $S$. sapinea are present in forest stands occurring on twigs, cones, and needles of pine. They represent a constant risk for infection due to airborne dispersal of conidia. A high latent infection rate may pose a large risk when there are disease-triggering factors, e.g., hail or insect feeding or extreme weather conditions such as heat and drought, as in the years 2018 und 2019 in Germany.

The question of whether $S$. sapinea is native in Germany could not be answered with the presented results but the wide endophytic distribution suggests that this is possible.

Sydowia polyspora was the fungus with the highest abundance in this study. Twenty-two percent of all isolates were identified as Sy. polyspora and it was detected on nearly all sites (99\%). Additionally, its infection rate in healthy trees was much higher than in the studied diseased pines. This is in agreement with the results of other studies, which demonstrate that $S y$. polyspora occurs often as an epiphyte or endophyte of conifers and is widely distributed around the world (Muñoz-Adalia et al. 2017; Pan et al. 2018). It was found to be the second most common fungus in twig tissues of $P$. sylvestris (Sanz-Ros et al. 2015). Sy. polyspora lives predominantly saprophytically on a dead plant material and occurs on previously damaged needles and twigs as a weak pathogen (Heydeck 1991). Ascomata and pycnidia appear on dead pine branches and needles (Gremmen 1977). Sy. polyspora is also a wound pathogen and a blue stain fungus (Sutton and Waterston 1970). This is contrary to observations that this species causes damage in other conifers (Butin 1964), e.g., current season needle necrosis (CSNN) on true fir (Talgø et al. 2010), distinct chlorosis, or discoloration of needles and phloem lesions in Pinus yunnanensis Franchet (Pan et al. 2018). Therefore, it seems to be a potential pathogen for the studied Scots pine trees.

Microsphaeropsis olivacea (basionym: Coniothyrium olivaceum Bonord.) was isolated from nearly all studied stands (97\%) and it was the third most common fungus in this study, with an abundance of $23 \%$. Surprisingly, M. olivacea is only mentioned in three other studies as an endophyte of pine (Petrini and Fisher 1988; Kowalski and Kehr 1992; Kowalski 1993). It is also an endophyte in other tree species (e.g., Hormazabal et al. 2005). Anamorphic, Coniothyrium-like fungi are often colonizers of wood and leaves of woody plants (Damm et al. 2008). M. olivacea is known to be plurivorous and was found on twigs and branches of Cytisus, Hedera, Laurus, Lycium, and Sambucus (Ellis and Ellis 1985). Recently it was found to be the causal agent of brown spine 
rot of Camelthorn (Alhagi maurorum Medik.) (Razaghi and Zafari 2016). Additionally, it was identified as an etiological agent of human skin infection (Guarro et al. 1999).

Truncatella conorum-piceae ( $\equiv$ Pestalotia conorum-piceae Tubeuf) was also a frequently isolated endophyte in this study (frequency 10\%, isolated on $98 \%$ of all sites). This was unexpected, because in other studies on endophytes in twigs of P. sylvestris no fungi allied to Truncatella s. 1. were mentioned (Petrini and Fisher 1988; Kowalski and Kehr 1992; Peršoh et al. 2010; Martínez-Álvarez et al. 2012; Sanz-Ros et al. 2015). This fungus is mainly a saprobe and is only known as a subsequent decomposer of pre-damaged needles of pine (Landeskompetenzzentrum Forst Eberswalde (LFE) 2016). In other tissues of Scots pine Truncatella angustata, respectively, Truncatella spp. were rarely isolated (Menkis et al. 2006; Menkis and Vasaitis 2010; Terhonen et al. 2011).

Desmazierella acicola ( $\equiv$ Verticicladium trifidum Preuss) is a common colonizer of pine needles (Martinović et al. 2016) but is also found as an endophyte in stems and xylem of pine (Petrini and Fisher 1988). The anamorphs fructify after needles fall through needle stromata (Maanen and Gourbière 1997) and apothecia occur on decaying needles. The increased occurrence of D. acicola in apparently healthy and symptomless trees in comparison with diseased pines could be explained by competition with other fungal strains colonizing the diseased twigs. The latter may inhibit the growth of D. acicola from its common niche, pine needles, into the shoots.

With regard to forest protection, the frequency of Xylariales species $(9 \%, 19$ species) is important, especially of Biscogniauxia mediterranea (frequency $2 \%$, found in $49 \%$ of the studied sites) and Biscogniauxia nummularia (frequency $0.7 \%$, found in $39 \%$ of the studied sites). Both species are known endophytes (Nugent et al. 2005), colonizers of hardwood, and pathogens that take advantage of the weakness of their hosts. They prefer warmer temperatures and seem to benefit from climate warming. In this study, $B$. mediterranea had a higher frequency in pine stands with oak trees or with neighboring oaks in the warmer climate of south Germany than in northern parts. Because it also causes Charcoal canker on Quercus suber L. and other hardwoods in countries of the Mediterranean Basin (Ragazzi et al. 2011; Henriques et al. 2014a, 2014b, 2015), the occurrence of $B$. mediterranea as an endophyte in pine could, in view of climate warming, be evaluated as a potential risk for neighboring oaks in the same forest stand. B. nummularia is known to fructify (anamorphic and teleomorphic) only on beech species (Fagus sylvatica and F. orientalis Lipsky) in Eurasia (Læssoe et al. 1999). It is a common endophyte of European beech, although it can induce severe damage, e.g., strip-cankers and wood decay on trees stressed by drought (Greenhalgh and Chesters 1968; Luchi et al. 2015). The occurrence as an endophyte is not confined to beech, as it was also found symptomless in pine, fir, and Douglas fir (authors own, unpublished results) and in other tree species (Petrini 1985). In Northwestern
Germany, beech is very often planted as advance regeneration under pine or is associated with pine. In view of global warming, this leads us to assign $B$. nummularia in pine as a potential risk for neighboring beech.

The diversity and number of fungal species detected from pine twigs in this study is higher compared with other studies on endophytes in twigs of $P$. sylvestris, where between 10 and 44 species were recorded (Petrini and Fisher 1988; Kowalski and Kehr 1992; Peršoh et al. 2010; Martínez-Álvarez et al. 2012; Sanz-Ros et al. 2015). One explanation for this difference seems to be the much higher number of twigs sampled in this study. Whether the isolation of endophytes on artificial culture medium fully reflects the natural colonization of pine twigs remains questionable. The reason for the low isolation rate of fungi in the Basidiomycota could not be clearly determined in the present study. Plausible explanations for these results in our endophyte isolation study may be that (1) few Basidiomycota fungi live in this ecological niche, (2) sampling and media culturing methods for isolation favored fungi in the Ascomycota, or (3) surface disinfestation of twigs was not effective in killing hyphae of fast-growing epiphytic fungi. Point three was evaluated in a study by Bußkamp (2018) and could be refuted.

In other comparable culture-based studies on endophytes in branches of Scots pine, no fungi in the Basidiomycota were detected (Petrini and Fisher 1988; Kowalski and Kehr 1992; Peršoh et al. 2010; Martínez-Álvarez et al. 2012; and Sanz-Ros et al. 2015). In an endophyte study of Scots pine and mistletoe by Peršoh et al. (2010), which used a culture-based isolation method, only a single basidiomycetous fungus was detected in the mistletoe. In a second study by Peršoh (2013), who worked with direct sequencing of plant tissue, the detection and identification of fungi in the Ascomycota and Basidiomycota were similar.

There is evidence that some endophytes cannot be cultured on nutrient medium (Allen et al. 2003; Arnold 2007; and Unterseher et al. 2007). Numerous studies have shown that Basidiomycetes, in particular, are undetectable on nutrient medium (Kowalski and Kehr 1992; Hoff et al. 2004; Lygis et al. 2005; Menkis et al. 2006; Zamora et al. 2008; Botella and Diez 2011; Sanz-Ros et al. 2015), which is why the detection of endophytes with the help of direct sequencing could be helpful. Ascomycetes that are not cultivable could thus also be detected (Arnold et al. 2007; Rajala et al. 2013, and SanzRos et al. 2015). Extraction of total DNA of studied tissues could be examined to better determine endophyte communities (Rajala et al. 2013). But the fact that this method cannot distinguish between endo- and epiphytes can be problematic, since surface sterilization may not destroy the DNA of the epiphytes (Schulz and Boyle 2005). A direct comparison between culture-based and molecular methods using needles from P. taeda was carried out by Arnold et al. (2007). Their samples were cultured on malt extract agar medium and analyzed with ITS and LSUrDNA. Their results suggest that when isolated on nutrient medium, fungi in the 
Basidiomycota were underrepresented, compared with results obtained by direct sequencing methods (Arnold et al. 2007). In contrast, Sordariomycetes were not adequately detected by direct sequencing of plant tissue (Arnold et al. 2007). Fungi in the taxonomic class Sordariomycetes are common endophytic fungi in plant tissue and comprised $31 \%$ of all isolations in the present study. Similar results were shown in studies by SanzRos et al. (2015), in which Sordariomycetes accounted for $32 \%$ of all isolations from pine branches.

Gazis et al. (2011) argue that many endophyte studies deal only with a single DNA locus. The fungal barcode ITS region is generally used to identify species presence, as in the present work. Advantages of focusing on the ITS region are that this marker is simple to amplify and that, due to its frequent use, many sequences for comparison are available in public data repositories. However, the use of ITS sequences poses problems, as it sometimes shows high intraspecific variation (Lacap et al. 2003). The use of the ITS sequence as barcode region of the fungal genome is insufficient in very diverse genera or species complexes (Lacap et al. 2003; Hoffman and Arnold 2008). The limits of using the ITS region for species delimitation were apparent in the present study, e.g., for the species of the genus Pestalotiopsis Steyaert (Maharachchikumbura et al. 2011, 2014) or the genus Diaporthe (Gomes et al. 2013). Another problem resulting from the use of ITS sequences is the lack of high-quality reference sequences in the databases (Bridge et al. 2003; Nilsson et al. 2006; Arnold et al. 2007). For improving the number of reliable sequences, initiatives for barcoding fungi were launched (e.g., www.fungalbarcoding.org). Nevertheless, these databases contain at present less than $1 \%$ of the expected diversity of fungi (Hawksworth 2012). The seasonal differences in the isolation frequency of Sy. polyspora and M. olivacea correspond well with physiological studies of these fungi (Bußkamp 2018). Sy. polyspora dominated in the summer months and had a temperature optimum at approx. $22{ }^{\circ} \mathrm{C}$ in vitro, whereas $M$. olivacea, which dominated in the colder months of the year, had an optimum temperature at approx. $12{ }^{\circ} \mathrm{C}$ in vitro.

In summary, a foundational baseline to describe naturally occurring fungal endophyte communities of Scots pine twigs in Germany was established. In the future, it may be possible to identify potential endophytic fungi that suppress $S$. sapinea.

Acknowledgments The authors are grateful for the great support of Peter Gawehn and Annette Ihlemann in the WAHYKLAS-project and thank Christine Weinert, Kerstin Herwig, Ulrike Frieling, and Sylvia Heinemann for technical support. We gratefully acknowledge native speaker Robert Larkin, who processed the manuscript. The authors are very connected and grateful to Marc A. Cubeta, Ph.D., Professor and Associate Director, Center For Integrated Fungal Research who improve and supported the manuscript. We also thank the anonymous reviewers for their valuable suggestions and comments.

Dedication The results are published in honor of Prof. Dr. Franz Oberwinkler, $\uparrow 15$ March 2018, Tübingen in memory of his 80th birthday, 22.05.2019.
Funding information Open Access funding provided by Projekt DEAL. Bundesanstalt für Landwirtschaft und Ernährung (BLE), Grant/Award Number: 28WC403105, Northwest German Forest Research Institute (NW-FVA)

\section{Compliance with ethical standards}

Conflict of interest The authors declare that they have no conflict of interest.

Open Access This article is licensed under a Creative Commons Attribution 4.0 International License, which permits use, sharing, adaptation, distribution and reproduction in any medium or format, as long as you give appropriate credit to the original author(s) and the source, provide a link to the Creative Commons licence, and indicate if changes were made. The images or other third party material in this article are included in the article's Creative Commons licence, unless indicated otherwise in a credit line to the material. If material is not included in the article's Creative Commons licence and your intended use is not permitted by statutory regulation or exceeds the permitted use, you will need to obtain permission directly from the copyright holder. To view a copy of this licence, visit http://creativecommons.org/licenses/by/4.0/.

\section{References}

Allen TR, Millar T, Berch SM, Berbee ML (2003) Culturing and direct DNA extraction find different fungi from the same ericoid mycorrhizal roots. New Phytol 160:255-272

Altschul SF, Madden TL, Schäffer AA et al (1997) Gapped BLAST and PSI-BLAST: a new generation of protein database search programs. Nucleic Acids Res 25:3389-3402

Arevalo J, Hidalgo-Díaz L, Martins I et al (2009) Cultural and morphological characterization of Pochonia chlamydosporia and Lecanicillium psalliotae isolated from Meloidogyne mayaguensis eggs in Brazil. Trop Plant Pathol 34:158-163

Arnold AE (2007) Understanding the diversity of foliar endophytic fungi: progress, challenges, and frontiers. Fungal Biol Rev 21:51-66

Arnold AE, Henk DA, Eells RL et al (2007) Diversity and phylogenetic affinities of foliar fungal endophytes in loblolly pine inferred by culturing and environmental PCR. Mycologia 99:185-206

von Arx JA (1981) The genera of fungi sporulating in pure culture, 3rd edn. J. Cramer, Vaduz

Balasuriya A, Adikaram NKB (2009) Some spatial, temporal and spatiotemporal considerations of wood decay of tea (Camellia sinensis), caused by Nemania diffusa (Syn. Hypoxylon vestitum). Crop Prot 28:273-279

Bernicchia A, Gorjón SP (2010) Fungi Europaei - Corticiaceae s.l. 12. Candusso. Italia

Bihon W, Burgess TI, Slippers B et al (2011) Distribution of Diplodia pinea and its genotypic diversity within asymptomatic Pinus patula trees. Australas Plant Pathol 40:540-548

Blodgett JT, Bonello P, Stanosz GR (2003) An effective medium for isolating Sphaeropsis sapinea from asymptomatic pines. For Pathol 33:395-404

Booth C (1971) The genus fusarium. Commonwealth Mycological Institute

Bosso L, Luchi N, Maresi G et al (2017) Predicting current and future disease outbreaks of Diplodia sapinea shoot blight in Italy: species distribution models as a tool for forest management planning. For Ecol Manag 400: 655-664. https://doi.org/10.1016/j.foreco.2017.06.044

Botella L, Diez JJ (2011) Phylogenic diversity of fungal endophytes in Spanish stands of Pinus halepensis. Fungal Divers 47:9-18 
Botella L, Santamaría O, Diez JJ (2010) Fungi associated with the decline of Pinus halepensis in Spain. Fungal Divers 40(1):1-11

Brady BLK (1979) Beauveria bassiana. CMI Descriptions of Pathogenic Fungi and Bacteria: 602

Breitenbach J, Kränzlin F (1984) Pilze Der Schweiz. Band 1: Ascomyceten. Verlag Mykologia, Luzern

Brener WD, Setliff EC, Norgren RL (1974) Sclerophoma phythiophila associated with a tip dieback of ju niper in Wisconsin. Plant Dis Rep 58:653-657

Bridge PD, Roberts PJ, Spooner BM, Panchal G (2003) On the unreliability of published DNA sequences. New Phytol 160:43-48

Brookhouser LW, Peterson G (1971) Infection of Austrian, Scots, and ponderosa pines by Diplodia pinea. Phytopathology 61:409

Bußkamp J (2018) Schadenserhebung, Kartierung und Charakterisierung des „Diplodia-Triebsterbens“ der Kiefer, insbesondere des endophytischen Vorkommens in den klimasensiblen Räumen und Identifikation von den in Kiefer (Pinus sylvestris) vorkommenden Endophyten. Universität Kassel

Butin H (1964) Über zwei Nebenfruchtformen von Sydowia polyspora (Bref. et v. Tav.) Müller. Sydowia 5

Butin H (2011) Krankheiten der Wald- und Parkbäume: Diagnose, Biologie, Bekämpfung, 4th edn. Verlag Eugen Ulmer, Stuttgart (Hohenheim)

CABI (2014) Sphaeropsis sapinea (Sphaeropsis blight). Invasive Species Compend

Carroll FE, Muller E, Sutton BC (1977) Preliminary studies on the incidence of needle endophytes in some European conifers. Sydowia 29:87-103

Chen C, Verkley GJM, Sun G et al (2015) Redefining common endophytes and plant pathogens in Neofabraea, Pezicula, and related genera. Fungal Biol 120:1291-1322

Crous PW, Groenewald JZ (2013) A phylogenetic re-evaluation of Arthrinium. IMA Fungus 4:133-154

Crous PW, Quaedvlieg W, Hansen K et al (2014) Phacidium and Ceuthospora (Phacidiaceae) are congeneric: taxonomic and nomenclatural implications. IMA Fungus 5:173-193

Damm U, Verkley GJM, Crous PW et al (2008) Novel Paraconiothyrium species on stone fruit trees and other woody hosts. Persoonia Mol Phylogeny Evol Fungi 20:9-17. https://doi.org/10.3767/ $003158508 X 286842$

Decourcelle T, Piou D, Desprez-Loustau M-L (2015) Detection of Diplodia sapinea in Corsican pine seeds. Plant Pathol 64:442-449

Desprez-Loustau M-L (2009) Alien Fungi of Europe. In: Handbook of alien species in Europe. Springer Netherlands, Dordrecht, pp 15-28

Desprez-Loustau M-L, Courtecuisse R, Robin C et al (2009) Species diversity and drivers of spread of alien fungi (sensu lato) in Europe with a particular focus on France. Biol Invasions 12:157-172

Domsch KH, Gams W, Anderson TH (1993) Compendium of Soil Fungi, Auflage: Reprint der Ausgabe von 1980. Atlantic Books, Eching

Drenkhan R, Tomešová-Haataja V, Fraser S et al (2016) Global geographic distribution and host range of Dothistroma species: a comprehensive review. For Pathol 46:408-442. https://doi.org/10.1111/ efp. 12290

Ellenberg H, Leuschner C (2010) Vegetation Mitteleuropas mit den Alpen in ökologischer, dynamischer und historischer Sicht, 6. Ulmer, Stuttgart

Ellis MB, Ellis JP (1985) Microfungi on land plants. An identification handbook, Microfungi Land Plants Identif Handb

EPPO (2020a) EPPO A2 List. https\%3A\%2F\%2Fwww.eppo.int\% 2FACTIVITIES $\% 2$ Fplant quarantine $\% 2$ FA2 list. Accessed 15 May 2020

EPPO (2020b) EPPO A1 List. https\%3A\%2F\%2Fwww.eppo.int\% 2FACTIVITIES\%2Fplant quarantine\%2FA1 list. Accessed 15 May 2020
EUFORGEN (2008) European forest genetic resources programme: Distribution maps of Pinus sylvestris. http://www.euforgen.org/ distribution-maps/.

Fabre B, Piou D, Desprez-Loustau M-L, Marçais B (2011) Can the emergence of pine Diplodia shoot blight in France be explained by changes in pathogen pressure linked to climate change? Glob Chang Biol 17:3218-3227

de Fávaro LC, L, de Melo FL, Aguilar-Vildoso CI, Araújo WL (2011) Polyphasic analysis of intraspecific diversity in Epicoccum nigrum warrants reclassification into separate species. PLoS One 6:e14828

Fisher PJ, Petrini O, Petrini LE (1991) Endophytic ascomycetes and deuteromycetes in roots of Pinus sylvestris. Nova Hedwigia 52: $11-15$

Flowers J, Nuckles E, Hartman J, Vaillancourt LJ (2001) Latent infection of Austrian and Scots pine tissues by Sphaeropsis sapinea. Plant Dis 85:1107-1112

Flowers J, Hartman J, Vaillancourt LJ (2003) Detection of latent Sphaeropsis sapinea infections in Austrian pine tissues using nested-polymerase chain reaction. Phytopathology 93:1471-1477

Fournier J, Magni J-F (2004a) Biscogniauxia nummularia. In: Pyrenomycetes Southwest. Fr. http://pyrenomycetes.free.fr/ biscogniauxia/html/Biscogniauxia_nummularia.htm. Accessed 8 Nov 2016

Fournier J, Magni J-F (2004b) Nemania diffusa. Pyrenomycetes Southwest. Fr, In http://pyrenomycetes.free.fr/nemania/html/ diffusa.htm.

Gardes M, Bruns TD (1993) ITS primers with enhanced specificity for basidiomycetes - application to the identification of mycorrhizae and rusts. Mol Ecol 2:113-118

Gazis R, Rehner S, Chaverri P (2011) Species delimitation in fungal endophyte diversity studies and its implications in ecological and biogeographic inferences. Mol Ecol 20:3001-3013

Gerlach W, Nirenberg H (1982) The genus Fusarium - a pictorial atlas. Mitteilungen Aus Biol Bundesanst Für Land- Forstwirtsch BerlDahlem

Giordano L, Gonthier P, Varese GC et al (2009) Mycobiota inhabiting sapwood of healthy and declining Scots pine (Pinus sylvestris L.) trees in the Alps. Fungal Divers 38:69-83

Gomes RR, Glienke C, Videira SIR et al (2013) Diaporthe a genus of endophytic, saprobic and plant pathogenic fungi. Persoonia Mol Phylogeny Evol Fungi 31:1-41

Greenhalgh GN, Chesters CGC (1968) Conidiophore morphology in some British members of the Xylariaceae. Trans Br Mycol Soc 51: 57-IN6. https://doi.org/10.1016/S0007-1536(68)80122-6

Gremmen J (1977) Fungi colonizing living and dead tissue of Pinus sylvestris and P. nigra. Kew Bull 31:455-460. https://doi.org/10. $2307 / 4119386$

Guarro J, Mayayo E, Tapiol J et al (1999) Microsphaeropsis olivacea as an etiological agent of human skin infection. Med Mycol 37(2):133-137

Guba EF (1961) Monograph of Monochaetia and Pestalotia. Harvard University Press, Cambridge, Mass

Hampel M (1970) Phoma eupyrena Sacc. ss. Wr. und Plectosphaerella cucumeris Kleb., zwei wenig bekannte Keimlingspathogene. Z Für Pflanzenkrankh Pflanzenschutz J Plant Dis Prot 77:225-227

Hansen K, Perry BA, Dranginis AW, Pfister DH (2013) A phylogeny of the highly diverse cup-fungus family Pyronemataceae (Pezizomycetes, Ascomycota) clarifies relationships and evolution of selected life history traits. Mol Phylogenet Evol 67:311-335

Hawksworth DL (2012) Global species numbers of fungi: are tropical studies and molecular approaches contributing to a more robust estimate? Biodivers Conserv 21:2425-2433. https://doi.org/10. 1007/s10531-012-0335-x

Hennebert GL (1973) Botrytis and Botrytis-like genera. Persoonia 7:183204 
Henriques J, Barrento M, Bonifacio L et al (2014a) Factors affecting the dispersion of Biscogniauxia mediterranea in Portuguese Cork oak stands. Silva Lusit 22:83-97

Henriques J, Nóbrega F, Sousa E, Lima A (2014b) Diversity of Biscogniauxia mediterranea within single stromata on cork oak. J Mycol 2014:1-5

Henriques J, Nóbrega F, Sousa E, Lima A (2015) Morphological and genetic diversity of Biscogniauxia mediterranea associated to Quercus suber in the Mediterranean Basin. Rev Ciênc Agrár 38: 166-175

Heydeck P (1991) Nadelschädigung und Triebsterben in Verbindung mit Sclerophoma pithyophila (Corda) Höhn. Wald 41:142

Heydeck P, Dahms C (2012) Trieberkrankungen an Waldbäumen im Brennpunkt der forstlichen Phytopathologie. Eberswalder Forstl Schriftenreihe 49:47-55

Hoff JA, Klopfenstein NB, McDonald GI et al (2004) Fungal endophytes in woody roots of Douglas-fir ( Pseudotsuga menziesii) and ponderosa pine (Pinus ponderosa ). For Pathol 34:255-271. https://doi.org/10.1111/j.1439-0329.2004.00367.x

Hoffman MT, Arnold AE (2008) Geographic locality and host identity shape fungal endophyte communities in cupressaceous trees. Mycol Res 112:331-344

Hormazabal E, Schmeda-Hirschmann G, Astudillo L et al (2005) Metabolites from Microsphaeropsis olivacea, an endophytic fungus of Pilgerodendron uviferum. Z Für Naturforschung C J Biosci 60: 11-21. https://doi.org/10.1515/znc-2005-1-203

Jong SC, Rogers JD (1972) Illustrations and descriptions of conidial states of some Hypoxylon species. Bull Wash Agric Exp Stn 71:1-51

Ju Y-M, Rogers JD, San Martin F, Granmo A (1998) The genus Biscogniauxia. Mycotaxon 66:1-98

Kowalski T (1993) Fungi in living symptomless needles of Pinus sylvestris with respect to some observed disease processes. J Phytopathol-Phytopathol Z 139:129-145

Kowalski T, Kehr R (1992) Endophytic fungal colonization of branch bases in several forest tree species. Sydowia 44:137-168

Kwaśna H (2008) Fungi inhabiting roots of trees and their stumps and their effect on growth of Armillaria. University of California, Berkeley

Lacap DC, Hyde KD, Liew ECY (2003) An evaluation of the fungal 'morphotype' concept based on ribosomal DNA sequences. Fungal Divers 12:53-66

Læssoe T, Scheuer C, Granmo A (1999) Biscogniauxia granmoi (Xylariaceae) growing in Europe. Österr Z Für Pilzkd 8:139-147

Landeskompetenzzentrum Forst Eberswalde (ed) (2016) Diagnose Report 2015. Arbeiten unter besonderer Berücksichtigung pilzlicher Organismen, Diagnostische

Langer G (1994) Die Gattung Botryobasidium Donk (Corticiaceae, Basidiomycetes). Cramer, Berlin [u. a]

Langer G, Bressem U, Habermann M (2011) Diplodia-Triebsterben der Kiefer und endophytischer Nachweis des Erregers Sphaeropsis sapinea. AFZ-Der Wald11:28-31

Lee I-S, Langer E (2012) New records of Hyphodontia species from Taiwan. Nova Hedwigia 94(1-2):239-244. https://doi.org/10. 1127/0029-5035/2012/0094-0239

Liu JK, Hyde KD, Jones EBG et al (2015) Fungal diversity notes 1-110: taxonomic and phylogenetic contributions to fungal species. Fungal Divers 72:1-197

Luchi N, Capretti P, Vettraino AM et al (2006) Early detection of Biscogniauxia nummularia in symptomless European beech (Fagus sylvatica L.) by TaqManTM quantitative real-time PCR. Lett Appl Microbiol 43:33-38. https://doi.org/10.1111/j.1472765X.2006.01920.x

Luchi N, Oliveira Longa CM, Danti R et al (2014) Diplodia sapinea: the main fungal species involved in the colonization of pine shoots in Italy. For Pathol 44:372-381
Luchi N, Capretti P, Feducci M et al (2015) Latent infection of Biscogniauxia nummularia in Fagus sylvatica: a possible bioindicator of beech health conditions. IForest - Biogeosciences For 9:e1-e6. https://doi.org/10.3832/ifor1436-008

Lundqvist N (1972) Nordic Sordariaceae s. lat. Almqvist \& Wiksells, Uppsala

Lygis V, Vasiliauskas R, Stenlid J, Vasiliauskas A (2004) Silvicultural and pathological evaluation of Scots pine afforestations mixed with deciduous trees to reduce the infections by Heterobasidion annosum s.s. For Ecol Manag 201:275-285

Lygis V, Vasiliauskas R, Larsson K-H, Stenlid J (2005) Wood-inhabiting fungi in stems of Fraxinus excelsior in declining ash stands of northern Lithuania, with particular reference to Armillaria cepistipes. Scand J For Res 20:337-346

van Maanen A, Gourbière F (1997) Host and geographical distribution of Verticicladium trifidum, Thysanophora penicillioides, and similar fungi on decaying coniferous needles. Can J Bot 75:699-710

Maharachchikumbura SSN, Guo L-D, Chukeatirote E et al (2011) Pestalotiopsis - morphology, phylogeny, biochemistry and diversity. Fungal Divers 50:167-187

Maharachchikumbura SSN, Hyde KD, Groenewald JZ et al (2014) Pestalotiopsis revisited. Stud Mycol 79:121-186

Maresi G, Luchi N, Pinzani P et al (2007) Detection of Diplodia pinea in asymptomatic pine shoots and its relation to the normalized insolation index. For Pathol 37:272-280

Martínez-Álvarez P, Rodríguez-Ceinós S, Martín-García J, Diez JJ (2012) Monitoring endophyte populations in pine plantations and native oak forests in northern Spain. For Syst 21:373

Martinović T, Koukol O, Hirose D (2016) Distinct phylogeographic structure recognized within Desmazierella acicola. Mycologia 108:20-30

Mason WL, Alía R (2000) Current and future status of Scots pine (Pinus sylvestris L.) forest in Europe. Investig Agrar Sist Recur For 9:317336

Menkis A, Vasaitis R (2010) Fungi in roots of nursery grown Pinus sylvestris: ectomycorrhizal colonisation, genetic diversity and spatial distribution. Microb Ecol 61:52-63

Menkis A, Vasiliauskas R, Taylor AFS et al (2006) Fungi in decayed roots of conifer seedlings in forest nurseries, afforested clear-cuts and abandoned farmland. Plant Pathol 55:117-129

Meyer W, Gams W (2003) Delimitation of Umbelopsis (Mucorales, Umbelopsidaceae fam. Nov.) based on ITS sequence and RFLP data*. Mycol Res 107:339-350

Millberg H, Boberg J, Stenlid J (2015) Changes in fungal community of Scots pine (Pinus sylvestris) needles along a latitudinal gradient in Sweden. Fungal Ecol 17:126-139

Minter DW (2006) Chaetomium globosum. CMI Descriptions of Pathogenic Fungi and Bacteria 1685

Mirza JH, Cain RF (1969) Revision of the genus Podospora. Can J Bot 47:1999-2048

Munck IA, Smith DR, Sickley T, Stanosz GR (2009) Site-related influences on cone-borne inoculum and asymptomatic persistence of Diplodia shoot blight fungi on or in mature red pines. For Ecol Manag 257:812-819. https://doi.org/10.1016/j.foreco.2008.10.023

Muñoz-Adalia EJ, Sanz-Ros A, Flores Pacheco JA et al (2017) Sydowia polyspora dominates fungal communities carried by two Tomicus species in pine plantations threatened by Fusarium circinatum. Forests 8:127. https://doi.org/10.3390/f8040127

Nawrot-Chorabik K (2013) The use of interactions in dual cultures in vitro to evaluate the pathogenicity of fungi and susceptibility of host plant genotypes. In: Petre M (ed) Environmental biotechnology - new approaches and prospective applications. InTech Open Access Publisher

Nawrot-Chorabik K, Grad B, Kowalski T (2016) Interactions between callus cultures of Pinus sylvestris and pine fungi with different trophic properties. For Pathol 46:179-186 
Nilsson RH, Ryberg M, Kristiansson E et al (2006) Taxonomic reliability of DNA sequences in public sequence databases: a fungal perspective. PLoS One 1(1):e59

Nugent LK, Sihanonth P, Thienhirun S, Whalley AJS (2005) Biscogniauxia: a genus of latent invaders. Mycologist 19:40-43. https://doi.org/10.1017/S0269-915X(05)00106-0

Oertel B (2003) Bibliographische Recherchen in der Mykologie. Ein Leitfaden für Leser im deutschsprachigen Raum und darüber hinaus. Z Mykol 69:3-42

Pan Y, Ye H, Lu J et al (2018) Isolation and identification of Sydowia polyspora and its pathogenicity on Pinus yunnanensis in southwestern China. J Phytopathol 166:386-395. https://doi.org/10.1111/jph.12696

Peršoh D (2013) Factors shaping community structure of endophytic fungi-evidence from the Pinus-Viscum-system. Fungal Divers 60: 55-69

Peršoh D, Melcher M, Flessa F, Rambold G (2010) First fungal community analyses of endophytic ascomycetes associated with Viscum album ssp. austriacum and its host Pinus sylvestris. Fungal Biol 114:585-596

Petrini LE (1985) Untersuchungen über die Gattung Hypoxylon (Ascomycetes) und verwandte Pilze. ETH Zürich

Petrini O (1991) Fungal endophytes of tree leaves. In: Andrews JH, Hirano SS (eds) Microbial ecology of leaves. Springer, New York, pp 179-197

Petrini O, Fisher P (1988) A comparative study of fungal endophytes in xylem and whole stem of Pinus sylvestris and Fagus sylvatica. Trans Br Mycol Soc 91:233-238

Phillips AJL, Alves A, Abdollahzadeh J et al (2013) The Botryosphaeriaceae: genera and species known from culture. Stud Mycol 76:51-167

Pinto PM, Alonso JAP, Fernández VP, Casero JJD (2006) Fungi isolated from diseased nursery seedlings in Spain. New For 31:41-56

Pirttilä AM, Pospiech H, Laukkanen H et al (2003) Two Endophytic Fungi in different tissues of Scots pine buds (Pinus sylvestris L.). Microb Ecol 45:53-62

Przybył K, Karolewski P, Oleksyn J et al (2008) Fungal diversity of Norway spruce litter: effects of site conditions and premature leaf fall caused by bark beetle outbreak. Microb Ecol 56:332-340

R Core Team (ed) R Core Team (2019). A language and environment for statistical computing. Available from: https://www.r-project.org/

Ragazzi A, Beatrice G, Moricca S (2011) First report of Biscogniauxia mediterranea on English ash in Italy. Plant Dis 96:1694. https://doi. org/10.1094/PDIS-05-12-0442-PDN

Rajala T, Velmala SM, Tuomivirta T et al (2013) Endophyte communities vary in the needles of Norway spruce clones. Fungal Biol 117:182-190

Razaghi P, Zafari D (2016) First report of Microsphaeropsis olivacea causing brown spine rot on Alhagi Maurorum in Iran. J Plant Pathol 98:377. https://doi.org/10.4454/JPP.V98I2.044

Rigling D, Heiniger U, Hohl H (1989) Reduction of Laccase activity in DsRna-containing hypovirulent strains. Phytopathology 79:219 223

Rogers JD, Ju Y-M, Adams MJ (2002) Home of the Xylariaceae. http:// mycology.sinica.edu.tw/Xylariaceae/frames.asp?qrySectionName= Hypoxylon\&qryIDstring=h075\&qryPart=t. Accessed 8 Nov 2016

Romeralo C, Diez JJ, Santiago NF (2012) Presence of fungi in Scots pine needles found to correlate with air quality as measured by bioindicators in northern Spain. For Pathol 42:443-453

Samson RA, Houbraken J, Thrane U et al (2010) Food and indoor fungi. CBS-KNAW Fungal Biodiversity Centre, Utrecht

Sanger F, Nicklen S, Coulson AR (1977) DNA sequencing with chainterminating inhibitors. Proc Natl Acad Sci 74:5463-5467

Sanz-Ros AV, Müller MM, San Martín R, Diez JJ (2015) Fungal endophytic communities on twigs of fast and slow growing Scots pine (Pinus sylvestris L.) in northern Spain. Fungal Biol 119:870-883
Schulz B, Boyle C (2005) The endophytic continuum. Mycol Res 109: 661-686

Sivanesan A, Holliday P (1971) Khuskia oryzae. CMI Descriptions of Pathogenic Fungi and Bacteria:

Slippers B, Wingfield MJ (2007) Botryosphaeriaceae as endophytes and latent pathogens of woody plants: diversity, ecology and impact. Fungal Biol Rev 21:90-106

Stadler M, Læssøe T, Fournier J et al (2014) A polyphasic taxonomy of Daldinia (Xylariaceae). Stud Mycol 77:1-143

Stanosz GR, Smith DR, Guthmiller MA, Stanosz JC (1997) Persistence of Sphaeropsis sapinea on or in asymptomatic shoots of red and Jack pines. Mycologia 89:525-530

Sutton BC, Waterston JM (1970) Sydowia polyspora. CMI Descriptions of Pathogenic Fungi and Bacteria:1-2

Swart WJ, Wingfield MJ (1991) Biology and control of Sphaeropsis sapinea on Pinus species in South Africa. Plant Dis 75:761-766

Swart WJ, Wingfield MJ, Knox-Davies PS (1987) Selective medium for isolating Sphaeropsis sapinea. Phytopathology 77:1387-1389

Talgø V, Chastagner G, Thomsen IM et al (2010) Sydowia polyspora associated with current season needle necrosis (CSNN) on true fir (Abies spp.). Fungal Biol 114:545-554

Tamura K, Stecher G, Peterson D, et al (2013) MEGA6: molecular evolutionary genetics analysis version 6.0. Mol Biol Evol

Terhonen E, Marco T, Sun H et al (2011) The effect of latitude, season and needle-age on the mycota of Scots pine (Pinus sylvestris) in Finland. Silva Fenn 45:301-317

Thünen-Institut (2014) Dritte Bundeswaldinventur - Ergebnisdatenbank. https://bwi.info/inhalt1.3.aspx?Text=1.04\%20Baumartengruppe\% $20($ rechnerischer\%20Reinbestand $) \&$ prrolle $=$ public $\&$ prInv $=$ BWI2012\&prKapitel=1.04.

Thünen-Institut (2020) How is the forest doing in Germany? The Forest Condition Survey (WZE; Level I monitoring) investigates this question. https:/www.thuenen.de/en/wo/projects/soil-protection-andforest-health/projekte-waldzustandserhebung/national-forestcondition-survey/. Accessed 24 July 2020

Unterseher M, Reiher A, Finstermeier K et al (2007) Species richness and distribution patterns of leaf-inhabiting endophytic fungi in a temperate forest canopy. Mycol Prog 6:201-212

Verkley GJM (1999) A monograph of the genus Pezicula and its Anamorphs. Stud Mycol 44:1-180

Verkley GJM, Dukik K, Renfurm R et al (2014) Novel genera and species of coniothyrium-like fungi in Montagnulaceae (Ascomycota). Persoonia Mol Phylogeny Evol Fungi 32:25-51

Weber E (2002) The Lecythophora-Coniochaeta complex: I. morphological studies on Lecythophora species isolated from Picea abies. Nova Hedwigia 74:159-185

White TJ, Bruns T, Lee S, Taylor J (1990) Amplification and direct sequencing of fungal ribosomal RNA genes for phylogenetics. In: Innis MA, Gelfand DH, Sninsky JJ, White TJ (eds) PCR protocols: a guide to methods and applications. Academic Press, New York, pp 315-322

Yuan Z, Verkley GJM (2015) Pezicula neosporulosa sp. nov. (Helotiales, Ascomycota), an endophytic fungus associated with Abies spp. in China and Europe. Mycoscience 56:205-213

Zamora P, Martínez-Ruiz C, Diez JJ (2008) Fungi in needles and twigs of pine plantations from northern Spain. Fungal Divers 30:171-184

Zare R, Games W (2003) Lecanicillium psalliotae. CMI Descriptions of Pathogenic Fungi and Bacteria: 1568

Publisher's note Springer Nature remains neutral with regard to jurisdictional claims in published maps and institutional affiliations. 